\title{
Periodizing and Historicizing German Afro-Americanophilia: From Counterculture to Post-Soul (1968-2005)
}

\author{
Moritz Ege, University of Munich \\ Andrew Wright Hurley, University of Technology Sydney
}

This essay continues our thinking through of the implications of scholarship on what we have called 'Afro-Americanophilia' in twentieth century Germany. We set out our reasons for using this term in the introduction to this special edition; however it is worth stressing again here that the term is intended to designate the African-Americancentredness of German interest in black culture, as opposed to the more generically 'African' that Negrophilia connotes, a term which is also often linked with a very specific phase in European culture, the 1920s. ${ }^{1}$ Especially in the wake of technologies like the jukebox, radio, film and television, and after defeat and Allied occupation in WWII, there has been a distinct German engagement with African American culture(s). ${ }^{2}$ Our term includes a deliberate juxtaposition (Black Power prefix; Greek suffix), which is intended to prompt attention to the tensions and ambiguities running through the 'love.' It is important to conceive of the complexity and implications of this love. In the

\footnotetext{
${ }^{1}$ As in our previous joint essay, the culturally constructed yet crucial categories 'black' and 'white' will not be put in quotation marks or begin with a capital letter on the following pages (unless there is a context of identity politics and emphatic cultural pride among protagonists), but they should nonetheless be read as highly debated, unstable signifiers (with real-world references and effects in experiences, identities and politics), not as 'neutral', sociological denominations.

${ }^{2}$ There are, of course, counterexamples, including the prominent novelist and ethnographer Hubert Fichte (1935-1986) whose works on African diasporic cultures and gay/queer sexuality spans the Black Atlantic, and the Africanist Janheinz Jahn (1918-1973) who, a few decades earlier, wrote on numerous African but sometimes also African American literatures, and collaborated with Léopold Sédar Senghor.
} 
hands of a white majority, Afro-Americanophilia might be personally and culturally enabling, but it can also involve racist projections, and can impose restrictive expectations on the people it supposedly loves.

As we noted in our first survey essay and the introduction to the special issue, our objective here is to sketch out phases or eras in the German uptake of 'Black cultural traffic,' based largely on recent literature, in order to obtain an overview of salient themes, distinctions, and political dynamics. We mean not to whitewash acts of AfroAmericanophilia, but neither to dismiss them out of hand. Rather we intend to enquire into the breadth, patterns and political implications and effects of specific instantiations of the Afro-Americanophilia theme. While this is again often a story of white German Afro-Americanophilia, the larger narratives also involves Afro-Americanophilia amongst Afro-Germans and Germans 'with a background in migration.'

Having followed a timeframe from imperial Germany through to the postwar in our first survey essay, here we begin with the turning point of the late 1960s, encapsulated by the emblematic year, 1968, when German Afro-Americanophilia modulated and intensified, and we follow that forward to a point approaching the present day. In the process, we contemplate the rise of interest in the Black Diaspora amongst the new social movements, second-wave feminism, and Afro-German activism in the 1980s. We also attend to important moments in the German reception and recontextualization of African-American coded popular music such as disco, techno and hip-hop, following some of the resonances evident in music journalism, literary writing and academia. This is not to deny that similar (or divergent) patterns may have existed in relation to Ernste Musik ['serious' or 'high' culture music], advertising, visual culture, film and literature. However, we have had to set some limits - complexity seems to increase in contemporary history - and we have thus focused most on the realms of popular music that are best known to us, and comparatively well covered in scholarly and/or popular literature. This essay also includes a discussion of the impact of migration, and the breakdown of previously unquestioned equivalences between Germanness and whiteness. In that context, we will point to the complex triangulation of desire that figured within the reception and appropriation of US rap music and hip-hop by diverse groups of young people in Germany in the context of cultural globalization. Overall, we argue that, in some respects, the contours of Afro-Americanophilia shifted 
considerably - the subject positions diversified and, especially in the course of the 1980s, new dynamics emerged that seemed to leave behind the ideas of racial 'authenticity' that had dominated German Afro-Americanophilia for a long time (and continue to do so in some of contemporary versions). Our final objective for this essay is to return to the question of periodization that we raised in the introduction to this special edition, so as to query what a timeframe-based overview can and cannot address; most importantly the question of structural continuities in patterns of twentiethcentury Afro-Americanophilia in Germany. We will plumb some of those continuities, and offer some conclusions on the usefulness of a periodization, notwithstanding.

\section{8-1975: Counterculture, post-counterculture and the consequences of immigration}

In an essay on '1968,' British cultural critic Kobena Mercer (1992) illuminates the global cultural role of the Black Power movement, and suggests that in the Englishspeaking world 'becoming black' was a collective white countercultural fantasy at this time. Such a pattern of fantasies also existed in Germany, and in some respects it marked a clear break in regard to earlier types of German Afro-Americanophilia. In the late 1960s and early 1970s, German understandings of blackness were constituted by a peculiar confluence of radical politics, sexual emancipation, and popular culture. In some prominent cases, the pre-existing, primitivistic semiotic pattern of mutual exclusivity or complementarity between white-German and black was supplemented by a new pattern of imaginary equivalence and calls for solidarity, as Moritz Ege identifies in his article in this special edition in greater detail.

Other new factors were important. The volume of German-language writing about African Americans and Black Diasporic culture-literature, politics and, to some extent, race and racism - increased markedly, as young (white) scholars began to specialize in African American Studies, and German presses published translations of key works on Black Diasporic populations in the USA, Haiti, Jamaica and Brazil. ${ }^{3}$ In such writing, academic research and contemporary cultural currents were closely intertwined.

\footnotetext{
${ }^{3}$ Most of these scholars wrote within the 1968 context, however others approached the topic from different historiographical traditions. For example, the (then) social-democratic historian Immanuel Geiss wrote books at this time on Pan-Africanism (1968) and African American history (1969). For bibliographies see: Ege (2007), Höhn and Klimke (2010, Boesenberg (2011), Gerund (2013).
} 
The new politics of affinity and solidarity, which spanned different sociocultural fields between politics, literature and music, again diverged in the two German states. In the West, solidarity with the Black Power movement and its struggle against the US 'power structure' was, like the larger-scale anti-Vietnam War movement, a form of protest against the West German government's close ally. In the East, the government of the German Democratic Republic (GDR) did not embrace the Black Power movement as such; however its citizens were encouraged to protest against the USA in prescribed ways. Officially sanctioned protest was therefore directed against the USA's treatment of some spokespeople of the Black Power movement, such as the philosopher and activist Angela Davis. ${ }^{4}$ This context made solidarity with the Black Power movement less attractive to some oppositionally minded East Germans.

Afro-Americanophilia was not the only genre of racially inflected '-philia' during the Sixties. In comparison with the more superficial 'exotica' fad of the 1950s, large numbers of individuals now appropriated cultural materials and practices from abroadliterature, furniture, clothing, food or music-more consciously, and attempted to integrate those products, signifiers, movements and affects into reformed ways of life, which they often understood in expressly political terms. ${ }^{5}$ The continuing role of particular racial imaginations and colonial histories in this new 1960s context is not well illuminated. But we can provisionally suggest that there was a tendency of wanting to supplement the 1950s novelty exoticism we outlined in our first survey essay (which self-described progressives or Alternative [alternatives] considered unsophisticated, consumerist and provincially German) with more earnest and wide-reaching forms of appropriation. Appropriation was not so much about momentary Bereicherung (enrichment) through consumption, but implied a transformation of the Self - at least,

\footnotetext{
${ }^{4}$ After the Marin county courthouse shooting Davis was listed on the FBI's Most Wanted list, leading to her arrest in 1970. Davis, who had studied in Frankfurt am Main (West Germany) and was a CPUSA member, became a household name in Germany. In the GDR, thousands of middle school children were encouraged to write postcards to Davis in prison. In the FRG, the New Left rallied to her support, culminating in the conference 'Am Beispiel Angela Davis' [With Angela Davis as an Example], organized by Frankfurt School scholar Oskar Negt, in 1972. After her release in 1972, East German State officials sought to share the stage with her on more than one occasion, most famously at the

Weltfestspiele der Jugend [World Festival of Youth] in East Berlin in 1973 (Höhn \& Klimke 2010, ch. 7; Gerund 2013).

${ }^{5}$ In this context, one could try to discern specific German groups by their particular geographic and cultural orientations and their practices of longing and appropriation. There were those who oriented themselves, more or less pragmatically, towards Italy, France, Spain, Denmark, Sweden, Greece, Great Britain, the USA generally, India, Palestine, Israel, South America, Morocco, or, in a different way, to China, as in the 'Chinoiserie' of post-1968 Maoist groups.
} 
this is how many people understood their own actions. Cultural commentatorspessimists and optimists alike - regarded such patterns as a flight from historically tainted Germanness. This interpretation is plausible, overall, but the fact that similar processes were going on all over the world complicates the picture. ${ }^{6}$ AfroAmericanophilia was one of many -philias, then, but it was distinct in a number of ways, particularly by virtue of its focus on the USA; that is, its allegiance with the 'other' side of the dominant Western world power, its strong articulation with popular culture, and its positioning in relation to the long-standing tradition of anti-black racism. ${ }^{7}$

These sociocultural processes are crucial for understanding the mindset of many members of a generation that later was to dominate (West) German culture and, in the late 1990s, politics through the Green Party and self-described progressive Social Democrats. They must, however, also be understood in terms of their interdependence with (and disconnect from) the large-scale labour migration that began in the 1960s. Labour migrants came to West Germany from Southern Europe (Italy, Spain, Portugal Greece and Turkey) and also, to a smaller extent, from Tunisia and Morocco in North Africa. Small numbers also came from South Korea. Although the Government put a stop to active recruitment in 1973, this did not halt actual migration, especially from Turkey, as family members followed their relatives who had come earlier. Immigration significantly and permanently changed the make-up of the country as well as the meanings of what Germanness may mean. In this context, there were new and rewarmed discourses about difference and alterity (Fremdheit), and such discourses touched on the African American world in various significant ways. For example, when referring to recent immigrants' living and working conditions the West German press used expressions like Die Neger Europas (Europe's negroes) and even 'N-----s.' Within the German contemporary imagination, the racial situation of the USA supplied the paradigm of diversity and exploitation in ethnically heterogeneous societies.

However, these were problematic discursive framings and analogies, not least because few of the immigrants were actually racially marked as black. The political scientist and historian Karin Schönwälder $(2001,2004)$ has demonstrated that West German policy-

\footnotetext{
${ }^{6}$ On the relationship of Anglophone hippies to Native Americans, for instance, see Stuart Hall's contemporary analysis (1968). For an analysis of the long-standing German fascination with Native Americans, see Penny (2013).

${ }^{7}$ On the latter, see Moritz Ege's article in this special issue discussing the distinct yet sometimes overlapping countercultural and popular modes of relation and appropriation.
} 
makers strove that migrants would be (white) 'European' rather than African or Asian, and the State put Non-Europeans under greater pressure to leave the country after their work contracts expired. ${ }^{8}$ There was an obvious, though not surprising contradiction between this ongoing structural exclusion of people of colour and the AfroAmericanophilia displayed in cultural quarters. However, despite restrictive labour migration policies, there were still more Black people in Germany than there had been in the $1950 \mathrm{~s}$, and not just within US Army garrisons. ${ }^{9}$ Afro-Germans born shortly after the war came of age. A small number, like the soccer player Erwin Kostedde and the actor Günther Kaufmann, rose to fame in the late 1960s (Kostedde \& Schmitz 2001; Majer O’Sickey 2001; Kaufmann 2004; Nagl \& Blankenship 2012). Some African American soldiers stayed on, as did a few touring artists and other travelers, as well as students, migrants, and refugees from a number of African countries. A Black German population was slowly growing - small in comparison to the population of Southern European immigrants-however it could hardly be called a group or community in the sociological sense, as there appears to have been little group consciousness, institutions, or interpretive resources that enabled cohesion, and there were still no prominent Black German spokespeople. On the contrary, many individuals seem to have felt the absence of community and a strong sense of isolation. This is not to say that these individuals were without agency when confronted by racism, including unwanted AfroAmericanophilia in their social milieu. ${ }^{10}$ On the experience of Black Germans at the time, there are pertinent observations in various collections and essays, and further historical work is in progress (Oguntoye et al. 1986; Wright 2004; Partridge 2012; on Afro-German autobiographic narratives, see Lauré al-Samarai 2004).

\section{5-1989: Alternative post-counterculture and feminist Afro-Americanophilia}

Between the fading-out of the student rebellion in the mid-1970s and reunification in 1989, cultural flows, appropriations and feedbacks become both more diffuse and complex. Musical culture and subcultural life worlds still formed dominant arenas of white Afro-Americanophilia, but the literary realm and left-wing, feminist and antiracist politics were also crucial. However, it becomes harder to pin down an overall

\footnotetext{
${ }^{8}$ The argument was made without explicit reference to racial categories. Instead, policy makers and bureaucrats referred to Non-European 'culture' and potential problems of 'integration,' thus foreshadowing the turn toward a 'racism without races' to use Etienne Balibar's (1991) resonant term. ${ }^{9}$ Precise numbers are hard to come by as race was a taboo subject for surveys.

${ }^{10}$ This could also include leaving the country. On such 'imperceptible politics' from a theoretical angle, see Papadopoulos, Stephenson and Tsianos (2008).
} 
cultural theme during this ('postmodern') period, at a time when signs, genres and milieus were diversifying, hopes for radical emancipation were being disappointed (or ended via repression), new subject positions and identity politics struggled for recognition, and conservatives were elected to government, both in the USA and in Germany. At the same time, it is important to keep in mind some basics of social history at the time: living standards continued to improve for large numbers of people in both countries, which allowed them more power to consume, and increasingly niche sensibilities. In the USA, the black middle class grew substantially, mostly outside of inner city areas, but poverty simultaneously took root, as inner city areas rapidly decayed and deindustrialization and drugs plagued poor communities, especially African American ones.

In Germany, the left-wing alternative culture and the so-called new social movements of the 1970s and 1980s like feminism, the anti-NATO peace movement, Third World solidarity groups and the environmental movement, formed an important socio-political milieu that in many ways grew out of the radicalism of the late 1960s (Reichardt \& Siegfried 2010; Reichardt 2014; and, in relation to Switzerland, Kuhn 2011). Here, the African American world was not the central point of reference when it came to 'foreign' places of longing-India, South America, and Native Americans may have been more significant — but it was important (Ege 2010; Penny 2013). While white Germans formed the great majority within these scenes, participants came from various backgrounds. These milieus contained diverse left-wing migrants (Greeks, Italians, Turks, Kurdish Turks, Iranians and others), who possessed different political orientations. The milieus also included a few African-American US army deserters and Black Panther sympathizers, albeit in small numbers (Bojadzijev \& Perinelli 2010: 144). If ways of life in Germany were partly liberalized and democratized at this time, as cultural historians like Detlef Siegfried (2006) argue, then it was partly the doing of these diverse milieux as well, and it did not happen without resistance. ${ }^{11}$

Nonetheless, white-Germanness and its 'interior' libidinal economies remained dominant within the new social movements, as the example of second-wave feminism

\footnotetext{
${ }^{11}$ Bojadzijev and Perinelli (2010) reminds us that even within the German context, cultural appropriation by 'normative' German subjects was by no means the whole story; agency was distributed among different subjects. On multi-faceted processes of internationalization, see also the work of historian Maren Möhring (2012) on 'ethnic' restaurants; on the role of foreign students in shaping protest movements since the 1950s, see Slobodian (2012).
} 
illustrates. ${ }^{12}$ In one of the few texts that explicitly take up this subject, American Studies scholar Sabine Broeck has critiqued how Afro-Americanophilia operated in German feminism at that time. On the one hand, she argues that many white German feminists of the 1970s used African American masculinity (and their attraction to African American men) as a foil, as a metaphor for more physical and grounded ways of being in the world, and thus as a pathway to personal liberation. In contrast to the post-Nazi German masculinities outlined by Dagmar Herzog (2005) but echoing deeper racial mythologies, African American men seemed to embody an 'uncompromised virility' (Broeck 2007: 102). ${ }^{13}$ A familiar raced coding of physicality versus intellectuality is coopted here into feminist concerns about (white) German disembodied intellectualism and ossified patriarchal ways of life.

On the other hand, German feminism's Afro-Americanophilia was not all about men. Writers and activists like Angela Davis and Alice Walker inspired German feminists and provided them with important reference points for political analysis. Just as importantly, these women also communicated ways of being in the world through aesthetics and affects (Broeck 2007, 2011; Gerund 2013). However, Broeck argues that black womanhood again primarily 'served ... white German women-identified women to satisfy both their aesthetic desire and their political need for an articulation of embodiment' (2011: 129). She stresses that despite the rhetoric of solidarity and liberation, there was little dialogue with African-Americans (or with Black Germans) in the 1970s and early 1980s. There were few attempts to understand racism other than as a metaphor for sexism or discrimination more generally, and in the exceptional cases German feminists tended to be concerned with situations in countries like the USA or South Africa, or with guest workers generically. Schematically put, black 'Others' remained 'other,' but were useful for the self-improvement of white 'egos' (Broeck 2011: 129). Only in the mid-1980s, through an increasing exposure to Black feminist writings, did the constellation change to some extent, a point to which we return below. The texts Broeck reviews, from the 1950s to the mid-1980s, display what she calls an

\footnotetext{
${ }^{12}$ For the purpose of this essay we count second-wave feminism as part of new social movements and alternative milieu, notwithstanding numerous disagreements about that association.

${ }^{13}$ For instance, Swiss feminist author Verena Stefan's influential best-seller Häutungen [Skinnings] which dissects the inherent violence of heterosexual relationships, deploys her sexual relations with a black man - presumably African-American - as a crucial step towards 'discovery of her rights and sexual claims as a white female' and ultimately her identification as a lesbian (Broeck 2007: 101). Although sexual fulfillment came with women, Stefan argued that black men 'inhabit[ed] their bodies more directly than white people' (Broeck 2007: 101).
} 
'abolitionist sentiment' [Stellvertreter (surrogate/proxy) abolitionism], spanning time, gender, and politics. She suggests that a 'local configuration of [American] sentiment' was taken up by white Germans for whom it underpinned their reception of black politics and cultural forms, thereby holding white German 'guilt' at a distance. Such sentiment, and this does not only concern the feminist context, could not however 'devise a critical epistemology which could have taken German anti-black racism, Germany's role in the history of the slave trade and colonialism, actual German implications in an international black diaspora, and a self-critical reading of white hegemony into account' (2011: 128).

Despite convincing critical historical evaluations like Broeck's, which resonate with current critiques in critical race/whiteness studies and cultural anthropology (Eggers 2005; Partridge 2012), we can interpret some of this history of German engagement in a more positive light as well. In a basic way, the interest in African American literature, and in female writers in particular, yields further proof of the relevance of African American thought for various social movements and their models of subjectivity throughout the $20^{\text {th }}$ century. It is also worth stressing that in this context a contentious international debate began to develop about the interdependence of racial and gender oppression. If white Germans began to question the would-be universality of their perspectives, then this is one of the few sites where they - and feminist intellectuals in particular - started to do so. Furthermore, despite the racializing implications of ideas about embodiment and the problematic resonances with sexualized cultural imaginaries of 'authentic' physicality, those ideas also broke oppressive social taboos, diversified ways of relating to the world and increased the freedom of choice in sexual partners for different groups of people. At the same time, of course, such choices did not occur in a setting devoid of power imbalances. ${ }^{14}$

\section{Afro-German activism and Afro-Americanophilia}

The main impulse prompting an awareness of race within feminism and the alternative culture came not from US authors, but from within Germany. A major break in the

\footnotetext{
${ }^{14}$ The most obvious point is that within the German citizenship and migration 'border regime,' Hess and Kasparek's term (2010), marriage allowed non-citizens access to longer-term residency permits, which gave a certain amount of power to white Germans, many of them women. Damani Partridge spells out the dynamic since the 1990s: 'What previously would have been abject beings become subjects, but in a way that preserves and even depends on their position as outsiders. In the contemporary German context, Black male bodies can be incorporated if White women see them as beautiful and if they successfully perform hypersexually. The process is not one of normalization, but of hypersexualization' (2012: 81).
} 
racial 'relationships of representation' (Hall 2013) occurred during the 1980s, as selforganized Black groups were formed in Germany and other parts of Europe (Blakely 2012). In the middle of the decade, a group of women writers, historians and activists, including May Ayim [then named Opitz], Katharina Oguntoye and others affirmed their identity as Afro-deutsch (Afro-German), and began to research Black German history and anti-black racism in Germany. The Black German organizations Initiative Schwarze in Deutschland (ISD, Blacks in Germany Lobby) and Schwarze Frauen in Deutschland (ADEFRA, Black Women in Germany) were founded, with other groups following. An important catalyst here was the African American Audre Lorde-'Black lesbian feminist mother poet warrior,' as she described herself — who gathered a group of Black German students and others at the American Studies Department of Freie Universität Berlin in 1984, when she was a visiting lecturer there. ${ }^{15}$ The landmark 1986 book by Oguntoye, Ayim and Schultz, Farbe bekennen. Afro-deutsche Frauen auf den Spuren ihrer Geschichte (translanted as Showing Our Colors. Afrogerman Women Speak Out [1991]) emerged from this grouping. Presented as 'A collective biography of Black history in Germany,' it consists of historical research, group discussions and portraits as well as poetry (Piesche 2012: 11. See also El-Tayeb 2011; Gerund 2013). Farbe bekennen marked a break in the relationships of representation in two ways. First, its authors articulated their experiences, shared historical research and postulated a diverse Afro-German collective subject unwilling to wear the masks that racial discoursesanti-black, exoticist and Afro-Americanophile — had created. Second, the book situated Afro-Germans within both Germany and a wider African or Black Diasporic world (Piesche 2012: 15). Meeting other Afro-Germans within a self-defined setting was empowering for many involved, particularly those who had grown up in an all-white environment, without much contact with their black parent. ${ }^{16}$ The book presented a critical feminist and Black Consciousness framework to the Black German communityto-be, as well as to a wider German audience. There was now a visible and vocal Black presence in Germany that could no longer be defined as 'outside' Germanness, and there were experts and Betroffene (affected parties) who were available to be consulted.

Thirty years on, Afro-German activism has an established history and has passed through various key moments. Difficult debates about the relationship between Black

\footnotetext{
${ }^{15}$ Dagmar Schultz, who was on the teaching faculty and had been politically active in the women's movement, assisted her. See Schultz's film, Audre Lorde: The Berlin Years 1984 to 1992 (Schultz 2012). ${ }^{16}$ Some participants had their own transnational networks of black relatives and friends (Piesche 2012).
} 
and white feminism, as well as between Afro-Germans, the African or Black Diaspora and other 'people of colour' have taken place (Wright 2004; Lauré al-Samarai et al. 2007). Nonetheless, many white Germans have continued to use their own ideas of blackness as if nothing had happened. ${ }^{17}$

For our discussion of Afro-Americanophilia, two points should be highlighted. First, Afro-German discourse extensively critiqued 'positive racism' and, implicitly, AfroAmericanophilia. In Farbe bekennen a number of women testify to the sexualized exoticism and heightened interest in das Fremde [the Other] that they experience as forms of everyday racism. For example, May Ayim (writing as May Opitz) discerns how exoticism works to construe Black Germans as alien (fremd) in their own world, often by associating them with pleasurable difference, and by the eternally recurring question, 'Where are you really from?' (see also Kilomba 2008). Laura Baum, who notes how blackness is still routinely conflated with Africanness, observes the process by which Germans 'attribute to African men and women that which they themselves lack' (1986: 149). Those attributes include 'a primordial sense of rhythm' and an ability to 'live out their emotions'. Within the alternative Öko-Milieu [environmental activist milieu], people like Ayim would be expected to have 'interesting stories' to tell on the basis of their 'race' — the flip side of the Alternative-scene Afro-Americanophilia mentioned by Broeck. Such 'positive' projections were problematic in themselves, and they also would not prevent difficulties arising elsewhere, for example when seeking to gain access to a nightclub with a black partner. ${ }^{18}$ Some contributors to Farbe bekennen stress their agency when dealing with 'positive' prejudice, showing how they can use it to their own advantage. But the overall attitude is summarized by Adema Adomako who comes to the conclusion that 'I have to keep my head up in a society that seems neutral, but isn't' (1986: 201). Farbe bekennen's critique of exoticism partly represents a 'Black knowledge archive' about the pathologies of whiteness and represents an exercise in ‘counter-memory’ (Eggers 2005; Campt 2004). Maureen Maisha Eggers (2005) remarks that Black Germans have built up a largely informal 'archive of knowledge' about the pathologies of whiteness where, for instance, white Germans' insecurities and defense

\footnotetext{
${ }^{17}$ Continuing debates about the legitimacy of performances in blackface, for instance in theatre performances of Genet's The Blacks or Dea Loher's Unschuld [Innocence], or in Günter Wallraff's 2009 undercover investigative journalism, which he undertook in blackface as a Somali tourist in Germany, are cases in point (Thurn 2014; Sieg 2015).

${ }^{18}$ Ayim points out the interrelatedness of these patterns (she also speaks positively about her experiences in cities like Paris and London where she did not feel constantly classified and judged).
} 
mechanisms are the root of their projections, rather than inherent characteristics of the objects of their love and derision. In sum, the book squarely confronted the German situation, and did so from a new perspective. These accounts made it very clear that white German Afro-Americanophilia was not an innocent practice, but part of tangible power relations.

The second point we would like to stress about Farbe bekennen is that the Black German movement of the 1980s should be understood in part through its complicated relationship with the African American world, since it relied heavily on African American thought, activism, and cultural heroes (Gerund 2013). The Afro-German activist and German Studies scholar Peggy Piesche stresses, for example, how the East German Angela Davis solidarity campaign was meaningful to her in her younger years, providing her with a glamorous yet serious role model. In a similar vein, Katharina Oguntoye (in Piesche 2012: 34) and Maureen Maisha Eggers (2005) discuss the American expatriate Josephine Baker as a role model in their own Afro-German biographies, drawing inspiration from how she attempted to circumvent and subvert stereotypes in her life (see our discussion of this aspect in our first survey essay in this special edition). These are not isolated cases. Michelle Wright speaks of an 'intense identification some Afro-Germans express towards African-Americans' (2010: 268). This would be very important in the rise of German hip-hop culture, too, in which some Black Germans prominently figure.

Here, then, is a type of German (and simultaneously Black Diasporic) AfroAmericanophilia that differs, in some ways radically, from what we have reviewed so far. Is it even appropriate or productive to speak here of 'German AfroAmericanophilia' or should we choose different terminology? After all, there are basic differences, experientially and politically. An individual who experiences racism and racialization in a society where, more often than not, whiteness functions as an unquestioned norm starts from a different position than white Afro-Americanophiles who opt into symbolic blackness, most likely during a brief phase in their life, and who probably never leave their place of privilege in the process. Practices of adaption and appropriation might seem very similar on the surface, but the meanings and their performative effects can be radically different. Very simply put, for Afro-Germans the politics of Afro-Americanophilia are likely to be much more emancipatory. This is a 
point that is convincingly made in critical discussions about race and appropriation (Aikins 2004). However, with these reservations in mind, we think it apposite to discuss these writings and activities under the title of German Afro-Americanophilia for several reasons. First, the term denotes a cultural theme, rather than offering a universal analysis of the politics of the phenomena. Second, there are practical similarities given that Black Germans, too, have had to appropriate various aspects of Black Diasporic culture individually and collectively, since Diasporic belonging takes practical, intellectual and emotional work, and does not just happen 'naturally.' Afro-German translations of US culture also had the potential for misunderstanding, and in both cases the mass media was an important factor. Not without reason, Michelle Wright (2010) uses the term 'becoming Black' when speaking of Black European experiences, including those of Black Germans. Indeed, many Afro-German activists were exposed to Black US culture through the same media as other Germans around them, and it was through mainstream media rather than a functioning community that many began to learn about the wider African Diasporic world (Wright 2010: 268). To denaturalize the connection is not to delegitimize it, however. Moreover, it is necessary to consider the differences and the similarities between white and Black forms of AfroAmericanophilia in Germany in order to avoid a facile conflation of race, cultural practice and identity politics. It staves off any tendency to bracket Blackness from Germanness. Even though Afro-Americanophile processes of appropriation and reproduction are based in hierarchical dualities of racial mythology, those processes cannot simply be conceptualized as a binary matter, but are multi-faceted and gradual.

This point becomes clearer in the realms of popular music, which remained a crucial arena of German Afro-Americanophilia in the late 1970s, 1980s and 1990s. In the following sections, we limit our discussion to selected soundings of popular music and its social worlds in that historical period. Music-based subcultural scenes must be understood as local versions of transnational genres and networks, and various scenes in Germany have taken up genres of global, African American coded popular culture and constructed different imageries, semantics, and performative dimensions. We start our soundings in the German reception of African American musical culture since the 1970s by returning to the GDR. We then move through different musical genres and subcultures in pre- and post-unification Germany where Afro-Americanophilia has figured. These areas include blues (and blues-rock), disco, techno, and hip-hop/rap. Our 
discussion again focuses on mimetic practices, on patterns of appropriation and on the diverse politics involved. The cultural significance and inter-subjective relevance of popular music depends not only on the discursive level. Questions of rhythm, melody, and sound are crucial for a more complete account of musical Afro-Americanophilia, but we do not attend to those matters in this survey essay. ${ }^{19}$

\section{Blues, blues-rock and the paradigm of authenticity}

In the German Democratic Republic, domestication and control of Western popular music replaced outright repression in the 1970s. Modernization and (limited) liberalization tendencies took hold; the obsessively political reading of African American popular music by the state began to recede into the background (Rauhut 2008). Nevertheless, informal groupings of young people outside state-sponsored organizations such as the Freie Deutsche Jugend [Free German Youth] were still seen as a threat, and some of these groups revolved around African-American culture. Indeed, the so-called Blueser [blues fans] formed the major oppositional youth subculture in East Germany in the 1970s and early 1980s. Aesthetically reminiscent of hippies, the Blueser assembled in more or less clandestine meetings all over the GDR (Kochan 2002; Rauhut 2008). Michael Rauhut argues that their 'almost religious' admiration for the blues was conditioned by both a traditional 'Euro-Romantic' image of AfricanAmericans as possessing existential 'authenticity,' and also by an identification with African American oppression (2008: 245). The blues became both 'free space' and 'counter world' for white East German adherents who saw in African American blues artists both an 'ancestral history of their own suffering' as well as 'emotional purity' (2008: 245). The Blueser were an important presence in eastern Germany after the fall of the Wall, and well into the 1990s. There were similar circles and dynamics among blues-rock afficionados in the alternative milieu of the West, but they did not have quite the same cultural significance. Overall, the Blueser and others constituted part of a strong cultural continuity of rockist, primarily male Afro-Americanophilia that stresses a sensibility it considers earthy, primordial, pure and existentially authentic, in touch with an inner human nature. In this strand of Afro-Americanophilia, positively-coded attributes like authenticity are - implicitly or explicitly — contrasted with contemporary European life, which includes both the demands of a rationalized, industrial society, as

\footnotetext{
${ }^{19}$ Nor can we attend to the significance of other changes in auditory cultures, such as those that are being analysed by scholars working in the field of sound studies (Eshun 1998; Weheliye 2005).
} 
well as a pop musical culture that is regarded as plastic. ${ }^{20}$ This, too, remains compatible with primitivist German and European traditions, and, partly with the Neger stereotype we discussed in our first survey essay.

In West Germany certain genres - initially blues-rock, then increasingly reggae - began to feature within the new social movements and left-wing Alternative culture and its institutions (Reichardt \& Siegfried 2010; Ege 2010; Reichardt 2014). Here, too, music was not just an entertaining commodity but crucial—sometimes foundational—for countercultural subjectivities and aesthetics. ${ }^{21}$

\section{Beyond authenticity: Munich disco and 'pop' sensibilities}

The blues (and reggae) fans, with their particular interest in the 'authentic' and their counter-cultural, critical disposition, form one end in a spectrum of music-cultural sensibilities of the late 1970s. At the same time, German 'pop' aesthetics were also becoming more complex, and in some cases self-aware and self-referential (Shahan 2013; Hurley 2015: 54, 79-80). Disco represents an important moment in German (and international) music history here. ${ }^{22}$ It provides an example of a popular musical genre rooted in African American culture and in signs of blackness, but distinct from the common paradigm of 'authenticity.'

The genre began in the early-to-mid 1970s and reached its international peak in the late 1970s, including in Germany. As the musicologist Peter Wicke has observed, in the mid-1970s, popular music entered a new moment in Germany and Europe (quoted in Wagner 1999: 113). If during late 1960s rock articulated with a sense of radical social upheaval — which, among some fans, included moments of symbolically 'becoming black' - then for many there was a change in mood during the early 1970s. Wicke

\footnotetext{
${ }^{20}$ There is a need for more differentiated analyses of these dynamics that go beyond such schematic descriptions. For a description of the survival of (and ambiguities in) 'rockist' notions of 'authenticity' in Germany into the 1990s and beyond, see Hurley (2015: 119-158), and the references cited there.

${ }^{21}$ We do not inquire here into the German reception and re-contextualization of reggae, nor its alignment with Alternative culture in Germany during the 1970s and 1980s (Karnik \& Philipps 2007; Schmidt 2002). However, the connection between the meanings of musical forms like reggae, alternative culture and emergent multiculturalism could be researched more extensively, especially in regard to the culturalist lens of difference and (more or less explicit) notions of authenticity held in that context. As an ideology, multiculturalism was taken up and elaborated in the context of the Alternative milieu, and it was (partly) institutionalized by left-leaning city governments like the one in Frankfurt am Main. On multiculturalism and German cultural policy, see Welz (1996), Knecht and Soysal (2007); Lanz (2007). Some versions of reggae also articulated with mainstream novelty exoticism in cultural works like the 1983 West German comedy film, Sunshine Reggae auf Ibiza (Sunshine Reggae on Ibiza).

${ }^{22}$ In post-punk, citation pop and other sub-genres, aesthetics of artificiality and intertextuality also emerged as concerns (Feiereisen 2011; Shahan 2013; Hurley 2015: 95-106).
} 
argues that in the 1970s many young people became more interested in hedonism rather than political upheaval as in the late-1960s (cited in Wagner 1999: 113). This especially held true for that majority of young people who were interested in popular music but lived outside of Alternative left-wing culture. ${ }^{23}$ On a musical level, Munich's scene illustrates the shift these writers talk about: whereas the late 1960s had spawned the radical music-commune, Amon Düül, by the mid-1970s it was home to Munich Disco.

Nelson George, an eminent writer on African-American popular music, has lamented that disco, especially 'white' varieties like Munich Disco, dealt a blow in the 'death of rhythm and blues,' which for him was an emphatically African American music (1990: 181-208). ${ }^{24}$ German authors and critics steeped in the rock tradition were similarly dismissive (Elflein 1998: 256; Witzel et al. 2005; Wagner 1999: 110-116). However, the music's intellectual supporters countered with a cultural-historical argument questioning narrow notions of authenticity, and such arguments are relevant to the history of German Afro-Americanophilia in a more general sense.

Disco emerged among African Americans and Latinas and Latinos in cities like Philadelphia and New York City in an ethnically diverse gay dance culture, and then became a world-wide mainstream pop phenomenon, popularized by musicians such as George McCrae. ${ }^{25}$ In Munich, the producer Giorgio Moroder (born Hansjörg Moroder in Southern Tyrolia, Italy) developed a Munich Disco style that relied heavily on synthesizers, most memorably in the 1977 Donna Summer hit, 'I Feel Love,' for which Summer, Moroder and Pete Bellotte were co-writers. Other German-based disco-pop producers, such as Frank Farian, who created Boney M, and Michael Kunze, also employed African-Diasporic and African people as writers, musicians, band members and stage performers, although not exclusively. Individual musical skills were sometimes decisive, but some choices may have been made because black (often female) bodies anchored the musical product in a type of appeal for producers and audience alike, they served as 'harbingers of the exotic and foreign' (Weheliye 2014).

\footnotetext{
${ }^{23}$ Such a perspective may well echo the 'rockist' counterculture's anti-disco stance, which some critics link to the anxieties of masculine heterosexuality faced with queer aesthetics and pleasure (Frank 2007).

${ }^{24}$ George's account of the role of radio audience research and the culture of musical corporations is particularly compelling in his tale of the 'death' of rhythm and blues. See also Perry Hall's pessimistic account (1997) of the effects that white appropriations of African-American music have had on musical developments, even though African-American musicians kept searching for new forms.

${ }^{25}$ McCrae's 'Rock Your Baby' was also a number one hit for ten weeks in Germany in 1974.
} 
In a few cases, blackness was also denoted in the titles of songs like Boney M's 'Everyone Wants to Dance Like Josephine Baker' (1989).

On the basis of existing scholarship, it is hard to contemplate what types of AfroAmericanophilia the German consumers of this music might have exhibited at the time. ${ }^{26}$ Was one less or more likely to generate fantasies of 'becoming black' whilst listening and dancing to this music in upper-middle class discos, or on the radio, compared with an earlier enthusiasm for soul music or jazz? In order to find out more about these dynamics of Afro-Americanophilia in disco music, including in networks of musical creation and value distribution, and in the lifeworlds of those it touched, it would be necessary to study in detail the semiotics and the materiality of the music itself, to assemble different accounts of the time, and to take into account the economic and contractual side of the music business. In addition, one would need to contemplate the social history of nightclubs and club-goers. In the latter context, Alexander Weheliye (2012) has already identified that many German disco-pop oriented discotheques and nightclubs were unusually diverse, cosmopolitan spaces.

Music historians and cultural critics have noted that the overall aesthetic of discoespecially when it became more electronic, as in the Munich Sound-was happy with artificiality, with the 'cheesy' rather than 'earthy' sounds and arrangements of soul music. The notorious criterion of authenticity, which had dominated the discourse of German Afro-Americanophilia, hence became problematic and perhaps even obsolete in this context. This did not just relate to the music's reliance on synthesizers. Munich Disco also witnessed the receding into the background of myths of personal or collective expression, given that some of it was produced electronically, that the production process was based on a clear division of labour between producer and musical workers, and that those who recorded the music were not necessarily those who performed it live. ${ }^{27}$ Despite Munich Disco's African-American roots and elements, and even though it often relied on associations with black performers, aesthetics, sounds and

\footnotetext{
${ }^{26}$ Dietmar Elflein correctly identifies a 'gap in sociological knowledge' here (1998: 256). Compare also the comparative lack of depth to Mark Terkessidis' fleeting discussion (2006). The lack of knowledge is closely connected to the intellectual left's dismissal of the disco scene as a-political, hedonistic and conservative - but maybe also to the fact that the 1970s and 1980s are only slowly being explored by historians. For a latterday appreciation of 'Mjunik Disco,' see Hecktor (2008).

${ }^{27}$ Similar modes of musical production had predominated in, for instance, the rhythm-and-blues era, and also pertained to German Schlager music. Some left-wing German critics applied a Marxist critique towards the alienation of session musicians from their labour (Harun Farocki cited in Witzel et al. 2005).
} 
bodies, such music may not have been considered as intrinsically 'black' a sound, as say soul music, reggae, afro-beat or funk. In many ways, Munich Disco superficially relied on aesthetics of blackness, and on black performers. But in other ways, Munich Disco could be read as implying a level of indifference toward racial coding.

\section{Post-Soul aesthetics: Techno and the Pop-Intellektuelle [pop intellectuals]}

Such tendencies seem to offer a possible way out of the primitivist paradigm. We can speak of racial de-semanticization here: A stress on music's sonic materiality, on physical experience and affect, whereby discursive anchoring becomes a secondary concern, or fades out in experience, so that specific sounds that could otherwise be read as 'soulful' and emphatically 'black' are decontextualized and do not necessarily stand for anything. This motif is relevant in a more fundamental sense to the development of electronic dance music, and this leads our discussion into the 1990s. Techno is a particularly relevant case to discuss here because African-American musicians in Detroit invented much of it, and at the same time it is often taken to be a particularly German music, both among Germans and internationally (more so than House music with its disco lineage). German musicians and deejays have made significant contributions to the field, and some popular interpretations have tended to emphasise the form's would-be Germanness (Kösch 1995; Weheliye 2012). ${ }^{28}$

To situate our discussion of techno and German Afro-Americanophilia, it is helpful to first contemplate an important shift in some African American culture in the 1980s and 1990s, namely the rise of a so-called 'post-soul aesthetic.' As Bertram Ashe points out, this sensibility 'lives in the unstable, wobbly interstices' between what many had hitherto regarded as the 'discrete cultural categories' of 'black' and 'white,' and amongst practitioners who 'use non-traditionally black cultural influences in their work' (2007: 611). Many African American artists and cultural workers who were born in or came of age during the Civil Rights era increasingly considered that 'the black aesthetic [was] much more than just Africa and jazz,' as one polemic had it (Ellis 1989: 234).

Such an aesthetic impinged on individual African-American artists who created musical forms like Detroit techno in the 1980s. Detroit techno had its own post-soul-indeed

\footnotetext{
${ }^{28} \mathrm{~A}$ full discussion of Afro-Americanophilia in techno would have to include the case of Westbam (Maximilian Lenz), one of Germany's most successful deejays, whose name, according to the artist himself, is an abbreviation of 'Westphalia Bambaataa,' echoing his home region in North-Western Germany and the African American music pioneer Afrika Bambaataa (see Westbam \& Goetz 1997).
} 
Germanophile - background; its protagonists were influenced by the electro-pop band Kraftwerk, and in more House-based forms, by synthesizer-based Munich Disco.

As with our speculative interpretation of Munich Disco, the post-soul sensibility would seem to forestall older forms of German Afro-Americanophilia or at least change the tone. It provides much less fodder for quasi-romantic ideas of black authenticity, as in the primitivist tradition that lived on in blues rock and reggae imaginaries in Germany. Nor does it support imagined resistance towards 'The Man,' as in 1960s and 1970s counterculture, Detroit techno group Underground Resistance notwithstanding. Postsoul also eschews more vague semiotic associations with 'black' sensuality and hedonism, as in disco and, perhaps, in disco-derived House music. ${ }^{29}$

In the 1990s, new, more self-aware - or perhaps more sublimated - forms of AfroAmericanophilia also emerged in the writings of German music journalists, musicians, and other intellectuals who made their own sense of post-soul techno, a music that is purportedly not primarily about 'meaning. ${ }^{30}$ In some cases, the music's historical emergence in black Detroit in the 1980s allowed for Afro-Americanophile interpretations in which these historical roots are interpreted as the essence of the music (Bachor 1995). Of most interest to our discussion however are the desemanticizing interpretations that have contemplated techno as what, for want of a better term, we might call 'Afro/German' (which is unlike the community appellation 'Afro-German'). For example the musician, broadcaster and writer Thomas Meinecke has been interested in the complex 'transatlantic feedback' between Afro-America and Germany, as well as in the mutually constituting imaginaries, and at a more prosaic level, in the decision by African-American DJ-composers to record and live in Germany, or collaborate with Germans. Here, Afro-Americanophilia becomes a highly self-reflexive matter that takes up a post-soul aesthetic where that which is being appropriated is quite conspicuously also white, European, and even German. An absorption with such complexities is evident in First Take then Shake, the 2004 collaborative recording by Meinecke's band, Freiwillige Selbstkontrolle [Voluntary Self Regulation], and the African American DJ Anthony 'Shake' Shakir. It is also an ongoing theme in Meinecke's 2001 Suhrkamp

\footnotetext{
${ }^{29}$ The voice and cultural meaning of the (African American) soul 'diva' in House music is explored in Jochen Bonz's ethnography (2008: 49-51) as constitutive for that musical world. Bonz refers to the cultural figure of a Black 'superwoman,' as analysed by Michelle Wallace (2000 [1979]).

${ }^{30}$ As a style of the future that is now 'sedimented' (Nye 2010), techno has been the subject of various German-language popular historical studies (see Denk \& van Thülen 2012; Rapp 2009).
} 
novel Hellblau [Pale Blue]. The latter refrains from presenting any neatly digested interpretations, but seeks to index music discourse about techno, among other foci, as a way of investigating the transnational. The novel's protagonists thereby query such categories as white and black, African American and German, just as Meinecke learned to do in his own appreciation of forms such as techno (Hurley 2012). The characters expressly précis and reflect upon Paul Gilroy's notion of the Black Atlantic and other writings from primarily British and US academic critical race and gender/queer theory, seeking to transpose them into a middle-European context.

Meinecke is among a number of un-dogmatic left-wing and anti-racist (white) German writers and Popintellektuelle [pop intellectuals] who, particularly since the mid-1990s, have written extensively on African American culture, politics, and criticism, as well as on the politics of Afro-Americanophilia - and have embodied it themselves. Among these writers are Günther Jacob, Tobias Nagl, and, most prominently, the music and art critic-cum-theorist Diedrich Diederichsen, a former editor of Spex magazine, a brainy, high-gloss music monthly. ${ }^{31}$ Diederichsen has co-edited a volume of African American cultural criticism (Yo! Hermeneutics!), co-organized a semi-academic conference on Afro-Futurism, 'Loving the Alien,' and co-edited the resulting book with Paul Gilroy, further mediating the 'Black Atlantic' to German audiences. Such writers provide numerous German musings on the question of why so many African American musical forms have encapsulated specific historic moments so powerfully, or otherwise had such purchase on listeners - why, simply put, Afro-Americanophilia is a very deserved love.

But techno was not the only music form to draw out such musings in the 1990s. There was also a sizeable discourse on rap and hip-hop, musical forms that, in contrast with techno, are not desemanticized in a post-soul way, but on the contrary are very clearly enmeshed in Black culture and politics, including cultural nationalism. Moreover, artists have often commented directly on questions of cultural ownership and exploitation. Hip-hop and rap became the dominant pop cultural aesthetic in the new millennium, something like a pop cultural lingua franca with many local varieties. ${ }^{32}$ They represent

\footnotetext{
${ }^{31}$ In Subito, a short story by the so-called Popliterat [pop-novelist] Rainald Goetz, a character supposedly based on Diedrich Diederichsen is named Neger Negersen [Negro Negrosen] (1983: 158). On Diederichsen, Spex, and the Advanced Music Journalism milieu in Germany, see Hurley (2015: 54-55, 79-83).

${ }^{32}$ Kenell Jackson speaks of the 'last surge of black cultural traffic' and one 'that we currently inhabit'; acknowledging that 'hip-hop has traveled to new places on a scale unimaginable for earlier black cultural
} 
the last cultural phenomenon we will consider in this essay-illustrating both the relevance and the complexity of Afro-Americanophilia in contemporary Germany.

\section{Rap and hip-hop}

In 1998 Tom Cheesman suggested that in Germany, rap and hip-hop-initially regarded as essentially African American cultural forms-'seem to have been received and adopted more enthusiastically than anywhere else in Europe' (1998: 194). ${ }^{33}$ Hence, and for at least twenty-five years now, the issue of Afro-Americanophilia has returned with a vengeance to the forefront of German cultural debates. In contrast to the last high point in the late 1960s, however, the underlying context is of a more diverse German society that has undergone shifts and developments via reunification and an emergent new nationalism, as well as globalization and transnationalism, forces recognized by social scientists and the wider public as major developments in the post-Cold War era. ${ }^{34}$

The German rap and hip-hop scene has long been pluralistic (Elflein 1998: 264). ${ }^{35}$ At the levels of production and reception, hip-hop has adopted various subject positions, some of which we elaborate below. Some musicians use the genre to express straightforward pop sensibilities and boy-meets-girl-stories. Some use the idiom to articulate their own social (ethnic, racial, class) marginality, which may or may not mean adopting (and adapting) a gangsta pose. Some express 'transracial' solidarity within the genre, and even anti-capitalist and anti-patriarchal politics. Others refracted the African-American cultural nationalism evident in some hip-hop into German variants. In the following section, we examine a few points in the complex history of German hip-hop, which represents a much larger phenomenon than earlier moments of Afro-Americanophilia such as the Negrophile 1920s or the counter-cultural late 1960s.

It is clear that the underground beginnings of rap in Germany did not just come about via the mediation of the culture industry, but also through people who bridged

material' (2005: 23). He also argues that the rise of hip-hop represents arguably the main reason for the surge of academic and intellectual interest in popular culture - and laments that this focus has led to a widespread disinterest in other forms of black cultural traffic. Given the importance of hip-hop, we nonetheless believe it is necessary to spell out its implications for Afro-Americanophilia here.

${ }^{33}$ We should note, however, that similar diagnoses have also been made about France, which has a very active rap music scene and is an important market for US-origin rap as well.

${ }^{34}$ See, for example, Arjun Appadurai's influential writings on transnational/global '-scapes' (1996).

${ }^{35}$ On the history of the German rap scene, see: Pennay (2001), Krekow and Steiner (2002), Verlan and Loh (2006), and Loh and Güngör (2002). On sociological aspects see: Menrath (2001), Kaya (2001), Androutsopoulos (2002), Bennett (2002), Bock et al. (2007), Brown (2006), Templeton (2006). On German 'gangsta rap,' see Szillus (2012), Dietrich and Seeliger (2012), and Ege (2013). 
continents. These actors included DJs and MCs who were African-American soldiers stationed in Germany, and who frequented nightclubs in cities such as Heidelberg/Mannheim, Stuttgart, Frankfurt and Berlin. From there, rap music moved into a small-scale, diverse youth-cultural scene, where the whole hip-hop package - rap, breakdancing and graffiti-was performed. This scene was fueled by music, hip-hop films like Beat Street, and the German-American co-production, Wild Style, as well as by various books and magazines that popularized hip-hop culture. The new medium of music television also played a significant role in making popular forms of rap more widely known, and in an audiovisual form. This was important because it meant that visual aspects and bodily styles could become key to local hip-hop culture. The scene comprised self-organized circles of enthusiasts, was supported by local cultural workers and youth centres, and formed the basis for 'old school' German rap.

The emergence of this early German hip-hop scene coincided roughly with reunification in 1990. The subsequent surge in nationalism, anti-immigrant and racist violence and anti-immigration policies in 1992 and 1993 brought issues of race and racism to the forefront, and these trends had impacts on German hip-hop. ${ }^{36}$ Some members of the early scene-itself socially, culturally and ethnically quite diverse-commented critically in their rhymes on everyday racism, and on the antiquated German citizenship laws. For example, Advanced Chemistry released a song titled 'Fremd im eigenen Land' [Foreign in my own country], an early German instance of conscious, message rap. Here, hip-hop represented a 'universal,' anti-racist youth culture where Germans of colour and Black Germans such as Torch could express an assertive political voice and, as it were, re-invent Afro-Americanophilia as a progressive project (Loh \& Güngör 2002).

The African-American origins of rap music and the concerns of African Americans did matter a great deal to many in this scene. However, contrary to the impression of hiphop skeptics who often ridiculed the scene as full of wannabe-blacks, AfroAmericanophilia was not necessarily the core concern on a lifeworld level. For many, the main thing was to master the performative aspects of hip-hop, and the dynamics of the social world in which it takes place, or universalist ideas of a global hip-hop culture. In any event, political and oppositional message rap has remained an important element

\footnotetext{
${ }^{36}$ The violence was, however, mostly not considered under the rubric of racism, but of Ausländerfeindlichkeit [hostility to foreigners].
} 
of German hip-hop. ${ }^{37}$ Again, there have been overlaps and convergences between musical-subcultural circles and leftist countercultural-political scenes. For many young Germans in the 1990s, including the 'white' majority, hip-hop played a crucial role in countercultural identity formation, where, to sketch just one important distinction, hiphop often articulated a more aggressive, masculinist sensibility than reggae. ${ }^{38}$ As in the early 1970s, contemporary popular music and radical political resistance again seemed to converge in the African American world, now represented in the figure of savvy, assertive, disciplined and emotionally 'cool' male rappers. ${ }^{39}$ German authors like Günther Jacob (2001) argue in this context that a great deal of rap is politically ambiguous, not least because it articulates an 'oppositional consciousness,' but can simultaneously convey what Angela Davis calls 'a nationalism packed with misogynistic undertones' (quoted in Diederichsen 1993: 210). Indeed, rap's association with misogyny and assertive masculinity became a watchword in German debates about rap's cultural significance. This again underscores how race, gender, and sexuality are interdependently defined, experienced and contested in German Afro-Americanophilia.

The first German-language pop-rap hits by Die Fantastischen Vier [The Fantastic Four] did not come from the subcultural 'old school' scene. Their 1992 hit song 'Die da' [Her over there] had a novelty feel to it, even parodying the hip-hop aesthetic (Verlan \& Loh 2006), and echoed other forms of exoticism in the 1950s or 1980s, or mimetic fads like the Cakewalk decades earlier. Most 'real' hip-hoppers despised this music, but similar songs and acts continue to play a role in German popular culture, including in the EuroDance genre, another genre of 'producers' music,' where the brief appearance of (mostly Black) rappers became de rigeur (Terkessidis 2006). ${ }^{40}$

Significantly, the reception of hip-hop in West Germany coincided with the coming of age of a generation of children of labour migrants and other Germans of colour, and quite a few of these young people, in addition to some from the smaller group of Black

\footnotetext{
${ }^{37}$ These forms found a high point during the wave of post-Wall xenophobia of 1992 and 1993, including on Rap gegen Rechts [Rap against the Right], a symbolic anti-nationalist music compilation, and, later on, in the (largely) Afro-German crew, Brothers Keepers, which formed in response to racist attacks (ElTayeb 2003; Weheliye 2009).

${ }^{38}$ Individuals in these circles often read Malcolm X's 1965 (auto-)biography, published in German in 1992.

${ }^{39}$ On Afro-German rap, gender and the reach for Blaxploitation (musical) iconography, see Layne (2013).

${ }^{40}$ In the late 1990s hedonistically-minded party rap crews such as Fettes Brot [Fat Bread] and Absolute Beginner [Absolute Beginners] bridged underground and mainstream, had more 'credibility' than Die Fantastischen Vier, and dominated rap music sales.
} 
Germans, gravitated towards rap and hip-hop culture's performative dimensions, fashion codes, ideology, and poses (Kaya 2001; Brown 2006; Gezen 2012: ch. 3; Stehle 2012). ${ }^{41}$ This segment continues to include people from very different backgrounds and in very different positions, who have made very different music in different languages, including Turkish and German. It would therefore be quite mistaken to construct Turkish-German rap or Migranten-Rap (rap by migrants) as a cohesive genre. Like elsewhere in Europe, however, there has been a recurrent and much commented-upon theme whereby (post-)migrant youth have sensed and/or claimed a similarity between aspects of African-American culture and experience and their own experience as minorities. ${ }^{42}$ Such appropriation, transfer and discursive comparison occur at the level of the aesthetics of everyday life. ${ }^{43}$ However, sometimes the music industry has also been involved, especially after the global turn toward gangsta rap during the 1990s. Under the tutelage of labels like Universal/BMG, 'ethnic' German gangsta rappers have performed to expectations of street-credibility and realness, long held by white adolescent German men. ${ }^{44}$ The commodification of realness became particularly clear around 2000, when various rappers from Berlin and Frankfurt am Main, aided by media-savvy entrepreneurs, including the independent Aggro Berlin label, started performing taboo-breaking battle rap lyrics as well as tough German street rap, stressing their connections to the underworld, and their street wisdom. The post-industrial cityscape, increasing social inequality in the post-unification era, neo-liberal social policies, as well as anti-immigrant racism and Islamophobia all provided the background for many such narratives and for the iconography of the ghetto, even though the structural situation was hardly comparable with postindustrial US cities. This broader phenomenon also included the controversial case of B-Tight, an Afro-German rapper from Berlin who, very much in tune with the over-the-top-sensibility of his

\footnotetext{
${ }^{41}$ This engagement has also been reflected upon in literature, especially by the Turkish-German writer Feridun Zaimoğlu's in his 1995 book, Kanak Sprak: 24 Mißtöne vom Rande der Gesellschaft [Kanaka Lingo: 24 Discordant Notes from the Margins of Society]. There is an extensive literature on Zaimoğlu and what Leslie Adelson has called the recent 'Turkish Turn' in German literature (see Cheesman 2002, 2007; Adelson 2005; Cheesman \& Yesilada 2012). For an analysis of the way Zaimoğlu's characters engage in Afro-Americanophilia, see especially Layne (2011: ch 6).

${ }^{42}$ Social anthropologist Ayse Çağlar has argued that this comparison was also promoted by many youth workers - a compelling argument that does not, however, explain the phenomena in toto.

${ }^{43}$ Rap music and hip-hop aesthetics have also been attractive to some young men in self-styled 'street gangs.' In Berlin-Wedding, for example, one 1980s predominantly Turkish gang named itself the 'Black Panterler' (Black Panthers) (Partridge 2012). These gangs began to form in the 1980s, for self-defence against racist attacks, to exert dominance over others, to kill time and to enjoy life.

${ }^{44}$ Similar dynamics are responsible for part of the success of gangsta rap in the USA, as various critics have pointed out (Rose 2008).
} 
label's roster, aggressively employed racist clichés of violence and sexual potency and was accused by Black German activists, among others, of exploiting and reinforming stereotypes and exploitative structures. There were a few Turkish- and Arab-German rappers, including 'Bushido,' who claimed to have close links with drug dealers and extortion networks. They simultaneously asserted that white German rappers were too soft and lacked street credibility. Some of these rappers even considered that the 'urban' hip-hop fashions of African-Americans, and of a sub-culturalist (but not 'street') hiphop scene in Germany, were less real, or even 'gay' (Ege 2013). A few rappers also used racist language to distance themselves from rap's African-American origins, and from Black claims to ownership of the culture (Aikins 2006). Such highly contradictory positions illustrate the ambiguities of a situation where Afro-Americanophilia and traditional racism are both important cultural patterns, where art forms based in the Black diaspora have simultaneously become part of a wider popular cultural repertoire and, to some extent, unmoored from their origins.

In a general sociological sense, turning social marginality and negative ascriptions into a glamorous, empowering aesthetics of living in a ghetto has been an important discursive strategy within the identity projects and, in some cases, political strategems of many underprivileged young people in Germany, among other places. ${ }^{45}$ Imagery derived from rap and hip-hop, but also from a wider world of gangsta culture, has played a crucial role in that process, as German rap music and rap videos show (Klein \& Friedrich 2004). This is not necessarily a serious trend-irony and self-reflexivity can figure prominently and a performative culture of 'dissing' is de rigeur. However, as Priscilla Layne (2011: ch. 6) has suggested of the German context, the strategy is a fraught one: it is very much open to debate how empowering are the iconographies of the ghetto and rampant forms of masculinity. ${ }^{46}$

The various positions towards straightforward racism and toward Afro-Americanophilia taken by Afro-German rappers such as Torch, Sammy Deluxe, Afrob, Harris, B-Tight,

\footnotetext{
${ }^{45}$ Compare, to name a few: Zaimoglu (1995); Tertilt (1996); Elflein (1998); Çağlar (1998); Soysal (2001; Cheesman (2002); Loh and Güngör (2002); Bennett (2003); Waegner (2004); Yildiz (2004, 2010); Brown (2006); Matthes (2008); El Tayeb (2011); Layne (2011: ch. 6); Stehle (2012); and Cheesman and Yesilada (2012).

${ }^{46}$ German hip-hop has also accommodated white nationalist strains, or what Dietmar Elflein calls 'hiphop nationalization' (1998: 260). This is the case with both the mid-1990s discourse of 'Neuer Deutscher Sprechgesang' [New German Recitative], which sought out German cultural precedents for rap, and later 'street rap' nationalists like 'Fler' (the so-called 'Deutscha Badboy').
} 
Liquid, Lisi, and many others would be another important approach for a multiperspectival history of Afro-Americanophilia in the hip-hop world. One could also analyze both the common question of whether being black has aided or rather hindered their careers, as well as the conditions under which the question has arisen (Klein \& Friedrich 2004; Layne 2013). ${ }^{47}$

But then again, sorting rappers by backgrounds, race and ethnicity, is of very limited use and quite obviously problematic. The heterogeneity of the list above is testament to that. In recent years, new sub-genres and pop-rap acts have flourished, and, overall, rap has become a familiar element of popular culture, such that it has lost any novelty character and is far from exotic or alien. As rap has become a dominant pop cultural form globally, there are indications that it has lost or shaken off the association with its US origins and become, at least potentially, another racially desemanticized idiom in a larger pop cultural repertoire. Our point here is not to try to represent this complexity in its entirety, but to acknowledge it, and to ask where it might leave the phenomenon of Afro-Americanophilia, and the racial dynamics from which it stems. In this arena, too, we encounter different forms that involve not so much a straightforward 'identification,' but rather a complex suite of recontextualizations, as well as the propagation and putting into discourse of stereotypical simplifications about African-America. There is not one version of Afro-Americanophilia in the context of German rap and hip-hop, but many, in which race is sometimes foregrounded and sometimes desemanticized.

\section{Some conclusions and questions}

At this point, it seems apposite to ponder what the literature we have surveyed has accomplished. Further, we must confront the inevitable question of whether there is a meta-narrative that makes sense of all the forms and patterns of Afro-Americanophilia in Germany that we have described, and that relates them to larger forces, to worldhistoric 'developments,' to structures of racism, and to the struggles against them. It is not our intent here to advance one major theoretical narrative, but rather to ponder the succession of historical conjunctures, and to suggest some analytical tools for understanding them. From the beginning, we have contended that excavating the practices and patterns of Afro-Americanophilia (in the widest sense) can contribute to a

\footnotetext{
${ }^{47}$ Klein and Friedrich's argument about blackness as a career booster in German rap is dubious given that the most successful German rappers have not been black.
} 
cultural history of Western-central Europe and the African Diasporas that acknowledges a variety of interconnections, contributions, overlaps, hybridizations, exploitative relationships and contestations. But we also heed the need to constantly re-think the terms with which to tell this narrative, and to invoke the fields and assemblages within which the practices, discourses, and affects of Afro-Americanophilia are situated.

Our provisional periodization, based on recent scholarship about popular music, subcultures, emancipatory politics, and literature, has allowed us to sketch the contours of some Afro-Americanophile conjunctures in Germany since the mid-19th century. We have assembled a wide variety of African-American presences, cultural forms and discourses, and although these moments have been scattered and heterogeneous, marshalling them together makes it clear that the cultural history of $20^{\text {th }}$-century Germany cannot adequately be told without reference to its Afro-Americanophile components, or in isolation of a wider world where people of the Black Diaspora have played crucial roles. German society and German peoples' lives have been considerably shaped by cultural forms that originated in Black Diasporic worlds.

As our essays have shown, the parameters determining the German fascination with, and appropriation of, African-American cultural forms have shifted considerably. The mid $-19^{\text {th }}$ century projection of abolitionism into a nationalist, romantic sensibility did not function in the same way as sexually coded, post-psychoanalytic 1920s primitivism, even though both partook of a common paradigm and ideology of white (European, Christian) supremacy. The binary complementarity and mutual exclusivity of 'black' and 'white,' which formed the semiotic basis for the racial re-valuations of early $-20^{\text {th }}$ century primitivism, was in some ways superseded by patterns of imagined equivalence in opposition to the power structure in late-1960s countercultural Afro-Americanophilia. Nevertheless, this latter moment also fed off the older pattern. There was never a complete replacement, as older patterns continued to affect exoticist strains of AfroAmericanophilia. Some forms, such as those during the 1950s Civil Rights Movement and among many feminists, had a strong ethical-moral tone, while others were much more hedonistically oriented. We could elaborate here on other patterns, but what we have already said suffices to make the general point about continuity and change. We have also sought to highlight different modes of Afro-Americanophile practices: intellectual engagement; consumption in carnevalesque moments; physical movement; 
practical solidarity; and subcultural aesthetics, to name a few. We have stressed that these engagements take place in different social worlds, and with different expectations of authenticity and commitment.

Through some historiographical fragments, we have related how Afro-Americanophile moments have impinged upon the social history of black people in Germany, for whom exoticist projections have often acted as an oppressive force. We have also mentioned, however, the covert forms of agency that are easily erased from such accounts, including for example tactical responses to the early German entertainment industry, and patterns of autonomy. We have stressed how Afro-Germans engaged in their own Afro-Americanophilia for political and cultural self-fashioning, particularly in the second half of the $20^{\text {th }}$ century. Juxtaposing a history of Afro-Americanophilia with the perspective of Black people is vital, although the latter perspective cannot be adequately understood from a vantage point such as ours; it must be told in its own right as AfroGerman history. Nevertheless, one of the most important aspects of our survey has been to highlight the growing contestation of some aspects of white Afro-Americanophilia by black people, in Germany and elsewhere, and how Afro-Americanophilia, as part of a transnational assemblage of forms and sentiments, has also functioned as a cultural resource for various migrant subjects and groups.

Even within our limited project of analyzing German Afro-Americanophile projections and practices of appropriation, there are some lacunae that we mentioned in the introductory section of this and our previous essay. These include an attention to how Afro-Americanophilia has played out in fields like advertising, film, theatre, reportage writing, photography, ethnography, classical music and sports (including basketball). Gay (such as in the work of Hubert Fichte), lesbian and/or queer narratives, which have been subtexts in some sections, would also add greatly to this wider history.

Analytically, we have barely touched upon the connections with the wider African Diasporic world and with mechanisms behind cultural flows. To do them justice, we would need to give a more detailed investigation of the processes of mediation in different genres and industries, of market dynamics, and of the ways different historical actors have interacted with them. We would also need to attend to specific transnational pathways. For example, we currently know little about how German attitudes to jazz may have been conditioned just as much by francophone jazz discourse, as they were by 
discourses in the USA, or, for that matter, by German experiences of expatriate Black Caribbean culture in the United Kingdom (see Detlef Siegfried's article on the key figure of Ernest Borneman in this special issue).

Most importantly, any periodization should not eclipse the question of whether different instances of Afro-Americanophilia in $20^{\text {th }}$ century German history are merely different versions of one common theme, of a longue-duree deep structure of racial dynamics that determines all of its superficial manifestations. Are we, in other words, witnessing a restaging of the same scene, over and over again? Our methodological decision to focus on specific conjunctures automatically downplays such continuities, but that is not to say that they are irrelevant. Numerous theorists of racism have stressed continuities in (white) misrecognition and privilege, including Sabine Broeck (2011), who has discerned a pattern of continuity from $19^{\text {th }}$-century 'proxy abolitionism' to postwar West German Afro-Americanophilia. Broeck argues that, under the surface, things essentially stayed the same for over a hundred years. Our essays, and the analytical distinctions between historical phases and conjunctures we have used, have queried that position. However, we recognize that it can be important to stress overarching continuities in unequal power relations and resources, both from an analytical and a political perspective. We acknowledge the basic point that, even in many of its later instantiations, white German Afro-Americanophilia was based on and perpetuated racist hierarchies that stemmed from desire and misrecognition. Still, we consider this point to be obvious enough to move on to micro-political analyses and attend to moments of reflexivity, challenge, and potential 'lines of flight' from the reproduction of racism. By gathering in scattered historiographical snapshots, a timeline of Afro-Americanophilia can also illuminate significant modulations in unmarked German whiteness. ${ }^{48}$ Our overview may thus add some situational and conjunctural specificity to what is oftenwith some justification, given its continuing effects of exclusion and dominanceregarded as a monolithic structural force.

How has unmarked German whiteness modulated in the period we have examined? Early forms of Afro-Americanophilia emerged in the context of a long-lasting formation of openly supremacist German whiteness, based in nationalism and understandings of

\footnotetext{
${ }^{48}$ This analytic category is problematic in the German context in that it can be used to downplay other forms of dominance and exclusion, most importantly anti-Semitism and the racism that targets immigrants and their descendants for reasons other than their non-whiteness; but it is indispensable.
} 
culture and civilization that were closely entangled with patterns of European colonialism, and attempts to legitimate it. African American popular culture was seen as self-evidently alien to German culture, despite some romantic currents. This idea was still rampant, and openly articulated in public discussions, in both German states into the 1970s, and it gave the Afro-Americanophilia of self-described progressives a particularly combative tone and resistant flavour.

In the new millennium, under the ambiguous conditions of globalization and new culturalisms, explicit cultural nationalist arguments are mostly - although not exclusively - to be found on the extreme right, and race-based definitions of national belonging are considered out of place in most polite discussion. Recent AfroAmericanophilia (for example in some German rap of the 1990s and 2000s) is part of that conjuncture, where formerly racial attributions and meanings are desemanticized. However, scholars like Fatima El-Tayeb (2011) have pointed out that such desemanticizing attitudes have not diminished the importance of whiteness as an unmarked norm and structure of dominance. Like many of their counterparts in the USA, many white Germans now assume that they are colour-blind, or even claim that they are not really white, which seems to denote a more relaxed mode of cultural identity (Sieg 2015). From a critical viewpoint, however, such statements can mask the inability to confront the ongoing privileges of being recognized as white in society that has not substantially confronted its racism, which it always situates elsewhere, abroad, among the 'less enlightened,' or below the line of middle-class respectability. Furthermore, contemporary white German self-definitions often express an omnivorous form, in which they (or should we say we?) consider themselves beyond the particularities of culture and history, free to consume at will, whereas numerous others are seen as fixed in time, space, and culture (El-Tayeb 2011). ${ }^{49}$ As a history of practices of appropriation Afro-Americanophilia has contributed significantly, even decisively, to such patterns.

Looking at changes to Afro-Americanophilia as it functions as a lingua franca across various social divides, especially its diversification into Afro-German or (post-)migrant variants, also allows us to explore how and when unmarked German whiteness has been challenged. Our chronological account has moved from histories of Fremdheit (Otherness/Alienness), told from the viewpoint of an imaginary racially homogenous

\footnotetext{
${ }^{49}$ Many similar middle-class ideas of the Self exist in other countries too (Skeggs 2005).
} 
national Self, to a contemporary scenario featuring diversity and contestation, where there is no clear, homogeneous national centre that defines what is other or exotic (Terkessidis 2002, 2006). In the process, Afro-Americanophilia has diversified to include shared, parallel, analogue forms and experiences of social and political marginality amongst many different Germans.

We have followed a largely Germany-centered timeframe, but ours has been a path of 'strategic methodological nationalism,' not intended to re-inscribe the importance of the national frame. In that sense, despite the ostensibly national focus of our two survey essays-'Afro-Americanophilia in Germany' - they have remained alive to the diversification in German society in the twentieth and twenty-first centuries, the transnational character of the Black Atlantic, to the waves and eddies in black cultural traffic, and to the changing ways that cultural coalitions can be marked out and challenged. If these essays can be used as a historiographic stepping-stone to a more empirically grounded post-national approach that adds more layers and re-configures the object of analysis, all the better.

\section{Reference List}

Adelson, L. A. 2005, The Turkish Turn in Contemporary German Literature. Palgrave MacMillan, New York \& Houndmills. doi: http://dx.doi.org/10.1057/9781403981868

Aikins, J. K. 2005, 'Wer mit Feuer spielt ... Aneignung und Widerstand—Schwarze Musik/Kulturen in Deutschlands weißem Mainstream' [Whoever Plays with Fire ... Appropriation and Resistance: Black Music/cultures in Germany's White Mainstream], in Mythen, Masken und Subjekte. Kritische Weißseinsforschung in Deutschland [Myths, Masks and Subjects: Critical Whiteness Studies in Germany], (eds) M. M. Eggers, G. Kilombo, P. Piesche \& S. Arndt. Unrast, Münster: 283-300.

Aikins, J. K. 2006, 'Des weißen Rappers Bürde. HipHop und Weißsein in Deutschland' [The White Rapper's Burden: Hip-Hop and Whiteness in Germany], in Heimatkunde. Migrationspolitisches Portal der Heinrich-Böll-Stiftung [Homelands-Studies: The Migration Politics Portal of the Heinrich-Böll-Fund]. Online, available: http://heimatkunde.boell.de/2006/12/18/des-weissenrappers-buerde-hiphop-und-weisssein-deutschland [accessed 27 July 2015].

Androutsopoulos, J. 2003, 'HipHop und Sprache. Vertikale Intertexualität und die drei Sphären der Popkultur' [Hip-Hop and Language: Vertical Intertextuality and the Three Spheres of Pop Culture]. in HipHop. Globale Kultur-lokale Praktiken [Hip-Hop: Global Culture, Local Practices], (ed.) J. Androutsopoulos. Transcript, Bielefeld: 111-136.

Appadurai, A. 1996, Modernity at Large: Cultural Dimensions of Globalization. University of Minnesota Press, Minneapolis.

Ashe, B. D. 2007, 'Theorizing the Post-Soul Aesthetic: An Introduction,' African American Review, vol. 41, no. 4: 602-623. doi: http://dx.doi.org/10.2307/25426980

Bachor, C. 1995, 'Detroit,' in Techno, (eds) P. Anz \& P. Walder. Ricco Bilger Verlag, Zurich: $78-83$.

Baker Jr., H. A., Diawara, M. \& Lindeborg, R. (eds) 1996, Black British Cultural Studies Reader. Chicago University Press, Chicago: 163-172.

Balibar, É. 1991, 'Is there a Neo-Racism?,' in Race, Nation, Class: Ambiguous Identities, (eds) É. Balibar \& I. Wallerstein. Verso, London \& New York: 17-28.

Basu, D. \& Lamelle, S. J. (eds) 2006, The Vinyl ain't Final: HipHop and the Globalization of Black Popular Culture. Pluto, London \& Ann Arbor. 
Bechheim-Gerst, M. \& Klein-Arendt, R. (eds) 2004, AfrikanerInnen in Deutschland und schwarze Deutsche: Geschichte und Gegenwart [Africans in Germany and Black Germans: in History and the Present Day]. LIT, Münster \& London.

Bennett, A. 2003, 'HipHop am Main: Die Lokalisierung von Rap-Musik und HipHop-Kultur' [Hip-Hop on the Main: The Localisation of Rap Music and Hip-Hop Culture], in HipHop: Globale Kultur, lokale Praktiken [Hip-Hop: Global Culture, Local Practices], (ed.) J. Androutsopoulos. Transcript, Bielefeld: $26-42$.

Blakely, A. 2012, 'Coda: Black Identity in France in a European Perspective,' in Black France/France Noire: The History and Politics of Blackness, (eds) T. D. Keaton, T. D. Sharpley-Whiting \& T. Stovall. Duke University Press, Durham, NC, \& London: 287-305. doi: http://dx.doi.org/10.1215/9780822395348-016

Bock, K., Meier, S. \& Süß, G. (eds) 2007, HipHop Meets Academia: Globale Spuren eines lokalen Kulturphänomens [Hip-Hop Meets Academia: Global Traces of a Local Cultural Phenomenon]. Transcript, Bielefeld.

Boesenberg, E. 2011, 'Reconstructing "America": The Development of African American Studies in the Federal Republic of Germany,' in Germans and African Americans: Two Centuries of Exchange, (eds) L. Greene \& A. Ortlepp. University Press of Mississippi, Jackson: 218-230.

Bojadzijev, M. \& Perinelli, M. 2010, 'Die Herausforderung der Migration: Migrantische Lebenswelten in der Bundesrepublik in den siebziger Jahren' [The Challenge of Migration: Migrant Lifeworlds in West Germany in the 1970s], in Das alternative Milieu. Antibürgerlicher Lebensstil und linke Politik in der Bundesrepublik Deutschland und Europa 1968-1983 [The Alternative Milieu: AntiBourgeois Lifestyle and Leftist Politics in West Germany and Europe, 1968-1983], (eds) S. Reichardt \& D. Siegfried. Wallstein, Göttingen: 131-145.

Bonz, J. 2008, Subjekte des Tracks. Ethnografie einer postmodernen/anderen Subkultur [Subjects of the Track: Ethnography of a Postmodern/Other Subculture]. Kadmos, Berlin.

Broeck, S. 2007, 'Blackness and Sexualities in the Interracial Diaspora,' in Black Sexualities, (eds) M. Wright \& A. Schuhmann. LIT, Münster: 95-106. 2011, 'The Erotics of African American Endurance, or, On the Right Side of History: White

(West)-German Public Sentiment Between Pornotroping and Civil Rights Solidarity,' in Germans and African Americans, Germans and African Americans: Two Centuries of Exchange, (eds) L. Greene \& A. Ortlepp. University Press of Mississippi, Jackson: 126-140.

Brown, T. S. 2006, "'Keeping it Real” in a Different 'Hood: (African-)Americanization and HipHop in Germany,' in The Vinyl ain't Final: HipHop and the Globalization of Black Popular Culture, (eds) D. Basu \& S. J. Lamelle. Pluto, London \& Ann Arbor: 137-150.

Çağlar, A. 1998a, 'Verordnete Rebellion. Deutsch-türkischer Rap und türkischer Pop in Berlin' [Enacted Rebellion: German-Turkish Rap and Turkish Pop in Berlin], in Globalkolorit. Multikulturalismus und Populärkultur [Global Colour: Multiculturalism and Popular Culture], (eds) R. Mayer \& M. Terkessidis. Hannibal,Vienna: 41-58. 1998b. 'Popular Culture, Marginality and Institutional Incorporation: German-Turkish Rap and Turkish Pop in Berlin,' Cultural Dynamics, vol. 10, no. 3: 243-261. doi: http://dx.doi.org/10.1177/092137409801000301

Cheesman, T. 1998, 'Polyglot Politics: Hip Hop in Germany,' Debatte, vol. 6, no. 2: 191-214. doi: http://dx.doi.org/10.1080/09651569808454589 2002, 'Akçam-Zaimoğlu_-“Kanak Attak”: Turkish Lives and Letters in German,' German Life and Letters, vol. 55, no. 2: 180-195. doi: http://dx.doi.org/10.1111/1468-0483.00223 2007, Novels of Turkish German Settlement: Cosmopolite Fictions. Camden House, New York.

Cheesman, T. \& Yesilada, K. (eds) 2012, Feridun Zaimoğlu. Peter Lang, Oxford, Bern, Berlin, Bruxelles, Frankfurt am Main \& New York.

Denk, F. \& von Thülen, S. 2012, Der Klang der Familie [The Sound of the Family]. Suhrkamp, Berlin.

Diederichsen, D., (ed.) 1993, Yo! Hermeneutics! Schwarze Kulturkritik-Pop, Medien, Feminismus [Yo! Hermeneutics! Black Cultural Criticism-Pop, the Media, Feminism]. ID-Verlag, Berlin \& Amsterdam.

Dietrich, M. \& Seeliger, M. 2012, 'G-Rap auf Deutsch. Eine Einleitung' [G-Rap in German: An Introduction], in Deutscher Gangsta-Rap: Sozial- und kulturwissenschaftliche Beiträge zu einem Pop-Phänomen [German Gangsta Rap: Social- and Cultural Sciences Approaches to a Pop Phenomenon], (eds) M. Dietrich \& M. Seeliger. Transcript, Bielefeld: 21-40.

Ege, M. 2007, Schwarz Werden. Afroamerikanophilie in den 1960er und 1970er Jahren [Becoming Black: Afro-Americanophilia in the 1960s and 1970s]. Transcript, Bielefeld. doi: http://dx.doi.org/10.14361/9783839405970 
2010, “Ich hab's damals intuitiv richtig erlebt, also Feeling gehabt": Blackness und die Selbsttechniken der Alteritätsaneignung zwischen Gegen- und Popkultur' [Back Then, I Experienced it Really Intuitively, Had the Feeling, You Know: Blackness and the SelfTechnologies of Appropriating Otherness, Between Counter- and Pop Culture], in Das alternative Milieu. Antibürgerlicher Lebensstil und linke Politik in der Bundesrepublik Deutschland und Europa 1968-1983 [The Alternative Milieu: Anti-Bourgeois Lifestyle and Leftist Politics in West Germany and Europe, 1968-1983], (eds) S. Reichardt \& D. Siegfried. Wallstein, Göttingen: 169184.

2013, 'Ein Proll mit Klasse.' Mode, Popkultur und soziale Ungleichheiten unter jungen Männern in Berlin [A Prole with Style: Fashion, Pop Culture and Social Difference Amongst Young Men in Berlin]. Campus, Frankfurt am Main \& New York.

Eggers, M. M. 2005, 'Rassifizierte Machtdifferenz als Deutungsperspektive der kritischen Weißseinsforschung in Deutschland' [Racialized Power Difference as a Critical Whiteness Interpretative Approach], in Mythen, Masken und Subjekte, (eds) M. M. Eggers et al. Unrast Verlag, Münster: 56-72.

Elflein, D. 1998, 'Some aspects of Hip-Hop history in Germany,' Popular Music, vol. 17, no. 3: $255-266$. doi: $\mathrm{http}: / / \mathrm{dx}$. doi.org/10.1017/S0261143000008539

Ellis, T. 1989, 'The New Black Aesthetic,' Callaloo, vol. 12, no. 1: 233-243. doi: http://dx.doi.org/10.2307/2931157

El-Tayeb, F. 2003, “If You Cannot Pronounce My Name, You Can Just Call Me Pride,” Afro-German Activism, Gender, and Hip Hop,' Gender \& History, vol. 15, no. 3: 460-486. doi: http://dx.doi.org/10.1111/j.0953-5233.2003.00316.x

El-Tayeb, F. 2011, European Others: Queering Ethnicity in Postnational Europe. University of Minnesota Press, Minneapolis.

Eshun, K. 1998, More Brilliant Than the Sun: Adventures in Sonic Fiction. Quartet, London.

Feiereisen, F. 2011, Der Text als Soundtrack—Der Autor als DJ: Postmoderne und postkoloniale Samples bei Thomas Meinecke [The Text as Soundtrack; The Author as Deejay: Postmodern and Postcolonial Samples in the Work of Thomas Meinecke]. Königshausen \& Neumann, Würzburg.

Frank, G. 2007, 'Discophobia: Antigay Prejudice and the 1979 Backlash against Disco,' Journal of the History of Sexuality, vol. 16, no. 2: 276-306. doi: http://dx.doi.org/10.1353/sex.2007.0050

Geiss, I. 1968, Panafrikanismus: zur Geschichte der Dekolonisation [Panafricanism: On the History of Decolonisation]. EVA, Frankfurt am Main. 1969, Die Afro-Amerikaner [The Afro-Americans]. EVA, Frankfurt am Main.

George, N. 1988, The Death of Rhythm and Blues. Pantheon Books, New York. 1990, Der Tod des Rhythm \& Blues [The Death of Rhythm and Blues]. Hannibal, Vienna.

Gerund, K. 2013, Transatlantic Cultural Exchange: African American Women's Art and Activism in West Germany. Transcript, Bielefeld. doi: http://dx.doi.org/10.14361/transcript.9783839422731

Gezen, E. 2012, Writing and Sounding the City: Turkish-German Representations of Berlin. Unpublished $\mathrm{PhD}$ Thesis, University of Michigan.

Goetz, R. 1984, 'Subito,' in Rawums, (ed.) P. Glaser. Kiepenheuer und Witsch, Cologne: 152-165.

Hall, P. A. 1997, 'African American Music: Dynamics of Appropriation and Innovation.' in B. Ziff, and P.A. Rao, eds., Borrowed Power: Essays on Cultural Appropriation. Rutgers University Press, Rutgers, 31-51.

Hall, S. 1968, 'The Hippies. An American Moment,' CCCS Stencilled Occasional Papers, no. 16. University of Birmingham, Birmingham. 1988, 'New Ethnicities,' in Black Film, British Cinema. BFI/ICA Documents No. 7. London, 2731.

2013, 'The Spectacle of the "Other,"' in Representation: Cultural Representations and Signifying Practices, (eds) S. Hall et al. $4^{\text {th }}$ edition. Sage \& Open University Press, London \& Milford Keynes: 215-287.

Hecktor, M. ed. 2008, Mjunik Disco. Blumenbar, Munich.

Heidkamp, K. 2007, It's All Over Now. Rowohlt Taschenbuchverlag, Reinbek.

Herzog, D. 2005, Sex After Fascism: Memory and Morality in Twentieth-Century Germany. Princeton University Press, Princeton.

Hess, S. \& Kasparek, B. (eds) 2010, Grenzregime. Diskurse, Praktiken, Institutionen in Europa [Border Regimes: Discourses, Practices, Institutions in Europe]. Assoziation A, Berlin.

Höhn, M. \& Klimke, M. 2010, A Breath of Freedom: The Civil Rights Struggle, African American GIs and Germany. Palgrave MacMillan, New York.

Hurley, A. W. 2012, 'Of Germanic Eddies in the Black Atlantic: Electronica and (Post-)national Identity in the Music of Freiwillige Selbstkontrolle (F.S.K.) and in Thomas Meinecke's Novel Hellblau 
(2001).' Journal of European Popular Culture, vol. 2, no. 1 (February): 65-80. doi: http://dx.doi.org/10.1386/jepc.2.1.65_1

2015, Into the Groove: Popular Music and Contemporary German Fiction. Camden House, Rochester, NY \& Woodbridge.

Jackson, K. 2005, 'Introduction: Travelling while Black,' in Black Cultural Traffic: Crossroads in Global Performance and Popular Culture, (eds) H. J. Elam, Jr., \& K. Jackson. University of Michigan Press, Ann Arbor: 1-42.

Jacob, G. 1993, Agit-Pop. Schwarze Musik und weiße Hörer. Texte zu Rassismus und Nationalismus, HipHop und Raggamuffin [Agit-Pop: Black Music and White Listeners. Texts on Nationalism, Hip-Hop and Ragamuffin]. ID-Verlag, Berlin \& Amsterdam. 2001, 'Die Modernisierung der Identität' [The Modernisation of Identity], Konkret, no. 7: 46-48.

Kaufmann, G. \& Droste, G. 2004, Der weiße Neger vom Haserlberg [The White Negro Of Haserlberg]. Droste, Munich.

Kaya, A. 2001, Sicher in Kreuzberg. Constructing Diasporas: Turkish Hip-Hop Youth in Berlin [Safe in Kreuzberg: Constructing Diasporas: Turkish Hip-Hop Youth in Berlin]. Transcript, Bielefeld.

Kilomba, G. 2008, Plantation Memories: Episodes of Everyday Racism. Unrast, Münster.

Klein, G. \& Friedrich, M. 2004, Is this real? Die Kultur des HipHop [Is This Real? The Culture of HipHop]. Suhrkamp, Frankfurt am Main.

Knecht, M. \& Soysal, L. (eds) 2007, Plausible Vielfalt. Wie der Karneval der Kulturen denkt, lenkt und Kultur macht [Plausible Multiplicity: How the Carnival of Cultures Thinks, Operates and Makes Culture]. Panama, Berlin.

Kochan, T. 2002, Den Blues haben. Momente einer jugendlichen Subkultur in der DDR [Having the Blues: Moments in an East German Youth Culture]. Lit, Münster.

Kösch, S. 1995, 'Mike Ink,' in in Techno, (eds) P. Anz \& P. Walder. Ricco Bilger Verlag, Zurich: 46-51.

Kostedde, E. \& Schmitz, W. 2001, 'Was macht eigentlich .... Erwin Kostedde?' [Where is Erwin Kostedde now?] Interview with Erwin Kostedde by Werner Schmitz. Stern, 9 October. Online, available: http://www.stern.de/lifestyle/leute/3-was-macht-eigentlich-erwin-kostedde-72560.html; http://www.11freunde.de/interview/erwin-kostedde-zieht-bilanz?page=1. [Accessed 24 July 2015].

Krekow, S. \& Steiner, J. 2002, Bei uns geht einiges: Die deutsche Hip-Hop Szene [Quite a Bit Happening Here: The German Hip-Hop Scene]. Schwarzkopf \& Schwarzkopf, Berlin.

Kuhn, K. 2011, Entwicklungspolitische Solidarität: die Dritte-Welt-Bewegung in der Schweiz zwischen Kritik und Politik 1975-1992 [Solidarity in Development Politics: The Third World Movement in Switzerland, Between Critique and Politics, 1975-1992]. Chronos, Zurich.

Lanz, S. 2007, Berlin aufgemischt: abendländisch, multikulturell, kosmopolitisch? Die politische Konstruktion einer Einwanderungsstadt [Roughed Up Berlin: Western, Multicultural, Cosmopolitan? The Political Constructions of a City of Migration]. Transcript, Bielefeld.

Lauré al-Samarai, N. 2004, 'Unwegsame Erinnerungen: Auto/biographische Zeugnisse von Schwarzen Deutschen aus der BRD und der DDR' [Impassable Memories: The Auto/biographical Statements of Black Germans from West and East Germany], in AfrikanerInnen in Deutschland und schwarze Deutsche: Geschichte und Gegenwart [Africans in Germany and Black Germans: In History and the Present Day], (eds) M. Bechheim-Gerst \& R. Klein-Arendt. LIT, Münster \& London: 197-210.

Lauré al-Samarai, N. et al. 2007, “Es ist immer ein Aufbruch, aber mit neuer Startposition”: Zwanzig Jahre ADEFRA und Schwarze Frauen/Bewegung in Deutschland: Nicola Lauré al-Samarai im Gespräch mit den Aktivistinnen Katja Kinder, Ria Cheatom und Ekpenyong Ani' [It is Always a Departure, But From a Different Starting Position: 20 Years of ADEFRA and the Black Women/Movement in Germany: Nicola Lauré al-Samarai in Discussion with the Activists Katja Kinder, Ria Cheatom und Ekpenyong Ani], in Re/visionen [Re/Visions], (eds) K. N. Ha, N. Lauré al-Samarai \& S. Mysorekar. UNRAST Verlag, Münster: 347-358.

Layne, P. 2011, Black Voices, German Rebels: Acts of Masculinity in Postwar Popular Culture. Unpublished PhD Thesis, University of California, Berkeley. 2013, 'One Like No Other? Blaxploitation in the Performance of Afro-German Rapper Lisi.' Journal of Popular Music Studies, vol. 25, no. 2: 198-221. doi: http://dx.doi.org/10.1111/jpms.12024

Loh, H. and M. Güngör 2002, Fear of a Kanak Planet. Zwischen Weltkultur und Nazirap [Fear of a Kanaka Planet: Between World Culture and Nazi Rap]. Hannibal, Höfen.

Majer O’Sickey, I. 2001, 'Representing Blackness: Instrumentalizing Race and Gender in Rainer Werner Fassbinder's The Marriage of Maria Braun,' Women in German Yearbook, no. 17: 15-29.

Matthes, F. 2008, 'Of Kanaken and Gottes Krieger: Religion and Sexuality among Feridun Zaimoğlu's Young Muslim Men,' Edinburgh German Yearbook, no. 2: 250-261.

Meinecke, T. 2001, Hellblau [Pale Blue]. Suhrkamp, Frankfurt am Main. 
Menrath, S.K. 2001, Represent what. Performativität von Identitäten im HipHop [Represent What: Performativity of Identity in Hip-Hop]. Argument, Hamburg.

Mercer, K. 1992, “'1968”: Periodising Politics and Identity,' in Cultural Studies, (eds) L. Grossberg et al. Routledge, New York \& London: 424-449.

Möhring, M. 2012, Fremdes Essen. Die Geschichte der ausländischen Gastronomie in der Bundesrepublik Deutschland [Strange Dining: The History of Foreign Gastronomy in West Germany]. Oldenbourg, Munich. doi: http://dx.doi.org/10.1524/9783486717792

Nagl, T. \& Blankenship, J. 2012, “So Much Tenderness”: Rainer Werner Fassbinder, Günther Kaufmann, and the Ambivalences of Interracial Desire,' in A Companion to Rainer Werner Fassbinder, (ed.)

B. Peuckert. Wiley-Blackwell, Chichester: 516-541. doi: http://dx.doi.org/10.1002/9781118275733.ch26

Nye, S. 2010, 'Minimal Understandings: Wolfgang Voigt and Uwe Schmidt on the Legacy of Techno.' Conference presentation at German Studies Association Conference, 7-11 October, Oakland California.

Oguntoye, K., Opitz [Ayim], M. \& Schultz, D. (eds) 1986, Farbe bekennen: Afro-deutsche Frauen auf den Spuren ihrer Geschichte [Showing Our Colors. Afrogerman Women Speak Out]. Orlanda, Berlin.

1991, Showing Our Colors. Afrogerman Women Speak Out. University of Massachussetts Press, Amherst.

Partridge, D. 2011, 'Exploding Hitler and Americanizing Germany-Occupying "Black” Bodies and Post-War Desire,' in Germans and African Americans, Germans and African Americans: Two Centuries of Exchange, (eds) L. Greene \& A. Ortlepp. University Press of Mississippi, Jackson: 201-217.

2012, Hypersexuality and Headscarves. Race, Sex, and Citizenship in the New Germany. Indiana University Press, Bloomington.

Pennay, M. 2001, 'Rap in Germany: The Birth of a Genre', in Global Noise: Rap and Hip-Hop Outside the USA, (ed.) T. Mitchell. Wesleyan University Press, Middletown: 111-133.

Penny, H. G. 2013, Kindred by Choice: Germans and American Indians since 1800. University of North Carolina Press, Chapel Hill. doi: http://dx.doi.org/10.5149/9781469607658 penny

Piesche, P. (ed.) 2012, Eurer Schweigen nützt euch nichts: Audre Lorde und die Schwarze Frauenbewegung in Deutschland [Your Silence Isn't Helping You at All: Audre Lorde and the Black Womens' Movement in Germany]. Orlanda, Berlin.

Rapp, T. 2009, Lost and Sound: Berlin, Techno und der Easyjetset [Lost and Sound: Berlin: Techno and the Easyjet-Set]. Suhrkamp, Berlin.

Reichardt, S. \& Siegfried, D. (eds) 2010, Das alternative Milieu. Antibürgerlicher Lebensstil und linke Politik in der Bundesrepublik Deutschland und Europa 1968-1983 [The Alternative Milieu: AntiBourgeois Lifestyle and Leftist Politics in West Germany and Europe, 1968-1983]. Wallstein, Göttingen.

Reinecke, C. 2012, 'Auf dem Weg zu einer neuen sozialen Frage? Ghettoisierung und Segregation als Teil einer Krisensemantik der 1970er Jahre' [On the Path to a New Social Question? Ghettoization and Segregation as a Part of the Semantics of Crisis in the 1970s], Informationen zur Modernen Stadtgeschichte [Information on Modern Urban History], no. 2: 110-131.

Rose, T. 2008, The HipHop Wars. What We Talk About When We Talk About Hip Hop and Why It Matters. Basic Civitas, New York.

Schmidt, R. 2002, Pop-Sport-Kultur. Praxisformen körperlicher Aufführungen [Pop-Sport-Culture: Practices of Bodily Performance]. UVK, Konstanz.

Schönwälder, K. 2001, Einwanderung und ethnische Pluralität. Politische Entscheidungen und öffentliche Debatten in Großbritannien und der Bundesrepublik von den 1950er bis zu den 1970er Jahren [Immigration and Ethnic Pluralism: Political Decisions and Public Debates in Great Britain and West Germany from the 1950s Until the 1970s]. Klartext, Essen.

Schönwälder, K. 2004, 'Why Germany's Guest Workers Were Largely Europeans: The Selective Principles of Post-war Labour Recruitment Policy,' Ethnic and Racial Studies, vol. 27, no. 2: 248265. doi: http://dx.doi.org/10.1080/0141987042000177324

Schultz, D., (dir.) 2012, Audre Lorde: The Berlin Years 1984 to 1992. Documentary, Third World Newsreel, New York.

Shahan, C. 2013, Punk Rock and German Crisis: Adaptation and Resistance After 1977. Palgrave Macmillan, New York. doi: http://dx.doi.org/10.1057/9781137337559

Sieg, K. 2015, 'Race, Guilt and Innocence: Facing Blackfacing in Contemporary German Theater,' German Studies Review, vol. 38, no. 1: 117-134. doi: http://dx.doi.org/10.1353/gsr.2015.0007 
Skeggs, B. 2005, 'The Re-Branding of Class: Propertising Culture,' in Rethinking Class: Culture, Idenities and Lifestyles, (eds) F. Devine, M. Savage, J. Scott \& R. Crompton. Palgrave Macmillan, Houndsmills: 46-68.

Slobodian, Q. 2012, Foreign Front: Third World Politics in Sixties West Germany. Duke University Press, Durham, NC. doi: http://dx.doi.org/10.1215/9780822395041

Soysal, Y. 2001, 'Diversity of Experience, Experience in Diversity: Turkish Migrant Youth Culture in

Berlin,' Cultural Dynamics, vol. 13: 5-28. doi: http://dx.doi.org/10.1177/092137400101300101

Stehle, M. 2012, Ghetto Voices in Contemporary German Culture. Textscapes, Filmscapes, Soundscapes. Camden House, Rochester.

Szillus, S. 'UNSER LEBEN_Gangsta-Rap in Deutschland. Ein popkulturell-historischer Abriss' [OUR LIFE: Gangsta Rap in Germany. A Pop-cultural Historial Sketch], in Deutscher Gangsta-Rap: Sozial- und kulturwissenschaftliche Beiträge zu einem Pop-Phänomen [German Gangsta Rap: Social- and Cultural Sciences Approaches to a Pop Phenomenon], (eds) M. Dietrich \& M. Seeliger. Transcript, Bielefeld: 41-64. doi: http://dx.doi.org/10.14361/transcript.9783839419908.41

Templeton, I. 2006, What's so German About It? Cultural Identity in the Berlin Hip Hop Scene. Unpublished PhD Thesis, Stirling University. (https://dspace.stir.ac.uk/handle/1893/75)

Terkessidis, M. 2002, 'Der lange Abschied von der Fremdheit: Kulturelle Globalisierung und Migration' [A Long Farewell to Otherness: Cultural Globalisation and Migration], Politik und Zeitgeschichte [Politics and Contemporary History], no. 12. Online, available: http://www.bpb.de/apuz/27032/der-lange-abschied-von-der-fremdheit [Accessed 27 July 2015]. 2006, 'Globale Kultur in Deutschland: Der lange Abschied von der Fremdheit' [Global Culture in Germany: A Long Farewell to Otherness], in Kultur-Medien-Macht: Cultural Studies und Medienanalyse [Culture-Media_-Power: Cultural Studies and Media Analysis], (eds) A. Hepp \& R. Winter. $3^{\text {rd }}$ edition. VS Verlag für Sozialwissenschaften, Wiesbaden: 311-325. doi: http://dx.doi.org/10.1007/978-3-531-90668-3_20

Thurn, N. 2014, 'Dieses Stück Genets wird jede deutsche Bühne überfordern. Zur Rezeption von Jean Genets "Les Nègres" in Deutschland' [This Piece by Genet Would Overtax Every German Theatre: On the Reception of Jean Genet's Les Negres in Germany], in Jean Genet und Deutschland [Jean Genet and Germany], (eds) M. N. Lorenz \& O. Lubrich. Merlin, Gifkendorf: 277-300.

Verlan, S. \& Loh, H. 2006, 25 Jahre HipHop in Deutschland [25 Years of Hip-Hop in Germany]. Hannibal, Höfen.

Waegner, C. C. 2004, 'Rap, Rebounds, and Rocawear: The "Darkening" Of German Youth Culture,"” in Blackening Europe: The African American Presence, (ed.) H. Raphael-Hernandez. Routledge, New York \& London: 171-186.

Wagner, P. 1999, Pop 2000: 50 Jahre Popmusik und Jugendkultur in Deutschland [Pop 2000: 50 Years of Pop Music and Youth Culture in Germany]. Ideal, Hamburg.

Wallace, M. 2000, Black Macho and the Myth of Superwoman. Verso, London \& New York [1979].

Weheliye, A. G. 2005, Phonographies: Grooves in Sonic Afro-Modernity. Duke University Press, Durham, NC. doi: http://dx.doi.org/10.1215/9780822386933 2009, 'My Volk to Come: Peoplehood in Recent Diaspora Discourse and Afro-German Popular Music,' in Black Europe and the African Diaspora, (eds) D. C. Hine, T. D. Keaton \& S. Small. University of Illinois Press, Urbana \& Chicago: 161-179.

2012, “'White Brothers with No Soul?" The Racial Politics of Berlin Techno.' Presentation at the Conference 'Radical Cross-Currents in Black Berlin,' Berlin: Humboldt-University, 27 July. n. d. 'Popular Orientalism(s) 2: Sonic Alterity_Race, Orientalism and Popular Music. Alexander Weheliye interviewed by Anta Helena Recke,' norient. Network for Local and Global Sounds and Media Culture. Online, available: http://norient.com/stories/orientalismus2/ [Accessed 17 May 2014].

Welz, G. 1996, Inszenierungen kultureller Vielfalt [Performances on Cultural Multiplicity] Akademie, Berlin, Frankfurt am Main \& New York.

Westbam and R. Goetz, 1997. Mix, Cuts and Scratches. Merve, Berlin.

Witzel, F., Walter, K. \& Meinecke, T. 2005, Plattenspieler [Record Players]. Nautilus Hamburg.

Wright, M. M. 2004, Becoming Black: Creating Identity in the African Diaspora. Duke University Press, Durham, NC.

Yildiz, Y. 2004, 'Critically "Kanak": A Reimagination of German Culture,' in Globalization and the Future of German, (eds) A. Gardt \& B.-R. Hüppauf. Mouton de Gruyter, Berlin \& New York: 319-340. doi: http://dx.doi.org/10.1515/9783110197297.319 2012, Beyond the Mother Tongue: The Postmonolingual Condition. Fordham University Press, New York. 
Zaimoğlu, F. 2007 [1995], Kanak Sprak: 24 Mißtöne vom Rande der Gesellschaft [Kanaka Lingo: 24 Discordant Notes from the Margins of Society]. Rotbuch, Hamburg. 